\title{
Old Weapon for New Enemy: Drug Repurposing for Treatment of Newly Emerging Viral Diseases
}

\author{
Deyin Guo ${ }^{1}$ (D)
}

Received: 29 January 2020 / Accepted: 31 January 2020 / Published online: 11 February 2020

(c) Wuhan Institute of Virology, CAS 2020

Emerging and re-emerging viral diseases are a public health concern for the whole world and pose a major threat to human health and life. In last decades, numerous major outbreaks of emerging and re-emerging viral diseases with gross public concern were recorded in different regions, including Ebola in western Africa, Zika in South America, H7N9 in China and many Asian countries, and H1N1 influenza worldwide. In particular, coronaviruses were once regarded as the ones that just cause mild symptoms like common cold, but three new types of coronaviruses, which emerged in the 21 st century, can cause severe diseases with high fatality and morbidity. Severe acute respiratory syndrome (SARS) coronavirus (SARS-CoV) emerged in November 2002 in Guangdong, China and caused globally 8098 human infections with 774 deaths (9.6\%), and the Middle East respiratory syndrome (MERS) coronavirus (MERS-CoV) emerged in 2012 in Saudi Arabia and caused 2494 infections with 858 associated deaths (34.4\%) as of November 2019 (WHO 2020a, b).

In December 2019, a dozen of patients with unusual pneumonia were hospitalized in Wuhan in central China, and the causative agent was identified as a new type of coronavirus (Zhu et al. 2020; Huang et al. 2020). The new virus was temporarily named as 2019 novel coronavirus (2019-nCoV) by the World Health Organization (WHO). As of January 29, 2020, 7736 confirmed cases of 2019-nCoV infection with 170 deaths were reported in China, and additional 77 cases in other 16 countries (National Health Commission of the People's Republic of China 2020; WHO 2020c). Since the emerging viruses are previously unknown pathogens, there are no specific and effective drugs available. Therefore, there is an urgent need for antiviral treatment in fighting the emerging viral

Deyin Guo

guodeyin@mail.sysu.edu.cn

1 The Centre for Infection and Immunity Studies, School of Medicine, Sun Yat-sen University, Guangzhou 510080, China diseases. However, the development of antiviral drugs is time- and resource-consuming, and thus repurposing of existing drugs to treat emerging viral diseases represents one of efficient strategies for drug development.

In a very recent work by a research team led by Drs. Gengfu Xiao, Wu Zhong and Zhihong Hu, the antiviral efficiency of the FDA-approved drugs including ribavirin, penciclovir, nitazoxanide, nafamostat, chloroquine (CQ) and two well-known broad-spectrum antiviral drugs remdesivir (RDV, GS-5734) and favipiravir (T-705) were evaluated against a clinical isolate of $2019-\mathrm{nCoV}$ in a cell culture infection model (Wang et al. 2020). The authors found that two compounds CQ $\left(\mathrm{EC}_{50}\right.$ value $=1.13 \mu \mathrm{mol} / \mathrm{L}$; $\left.\mathrm{CC}_{50}>100 \mu \mathrm{mol} / \mathrm{L}, \quad \mathrm{SI}>88.50\right)$ and $\mathrm{RDV} \quad\left(\mathrm{EC}_{50}=\right.$ $\left.0.77 \mu \mathrm{mol} / \mathrm{L} ; \mathrm{CC}_{50}>100 \mu \mathrm{mol} / \mathrm{L} ; \mathrm{SI}>129.87\right)$ potently blocked virus infection at low-micromolar concentration and showed high selectivity index (SI). From the in vitro results, these two compounds appear promising to be transformed into clinical drugs for treatment of 2019-nCoV infections.

$\mathrm{RDV}$ is an adenosine analogue prodrug and can be incorporated into nascent chains of viral RNA, resulting in pre-mature termination of RNA synthesis. RDV has been shown to possess a potent and broad-spectrum antiviral activity against a diverse panel of RNA viruses such as SARS-CoV, MERS-CoV, Ebola virus (EBOV), Marburg virus, Nipah virus, Hendra virus, and respiratory syncytial virus in cell culture and mouse infection models (Warren et al. 2016; Sheahan et al. 2017; Lo et al. 2017). Currently, it is in clinical trials to evaluate its efficacy against Ebola virus infections. The study by Wang et al. (2020) extends its antiviral activity to the new deadly coronavirus 2019-nCoV. However, RDV has not been used in any clinical treatment, and the clinical effectiveness and safety needs to be further investigated.

Remarkably, CQ was identified as a potent inhibitor against 2019-nCoV in cell culture infection model (Wang et al. 2020). CQ, a weak base 4-aminoquinolone derivative, has been used as a standard antimalarial drug for more than 
half a century for its rapid schizonticidal activity against all malarial parasite infections. CQ also has anti-inflammatory properties and has been approved for the clinical treatment of autoimmune diseases such as lupus erythematosus and rheumatoid arthritis (Rainsford et al. 2015). Recently, CQ has been proven to have a broad-spectrum antiviral activity against a panel of viruses, including SARS-CoV, MERS$\mathrm{CoV}$, EBOV, influenza A virus, Chikungunya virus, human immunodeficiency virus, dengue virus, West Nile virus, Crimean Congo hemorrhagic fever virus, and hepatitis A virus (García-Serradilla et al. 2019). It is not surprising that CQ can suppress the infection of a diverse group of viruses. CQ can efficiently enter the cells and accumulate in acidic compartments like lysosomes, endosomes and trans-Golgi network vesicles, consequently raising their $\mathrm{pH}$ value while many viruses need the acidic endocytic organelles at some stages of their replication, such as viral uncoating and cellular entry via membrane fusion. CQ is also able to impair the maturation of viral proteins and post-translational modification viral receptors like ACE2 for SARS$\mathrm{CoV}$ by inhibition of $\mathrm{pH}$-dependent enzymes such as proteases or glycosyltransferases (Savarino et al. 2003).

In view of its antiviral activity to SARS-CoV and MERS-CoV, it is not unexpected that CQ possesses an antiviral activity against 2019-nCoV. However, this finding is clinically important and timely as the $2019-\mathrm{nCoV}$ is currently spreading rapidly in China and causing severe respiratory diseases and deaths of many patients. As CQ is the first-line drug for the treatment of malaria and other illnesses with a proven safe record for several decades, it most likely represents the best candidate to be applied and evaluated immediately in the clinical treatment of acute 2019-nCoV infections. For benefits of 2019-nCoV patients, it is suggested that the potential clinical use of CQ be exploited and its efficacy evaluated during the 2019-nCoV epidemics. All the repurposed uses of CQ in the treatment of viral diseases should comply with the regulations of the administrative authorities and medical ethics. Although CQ belongs to the safest antimalarial drugs ever discovered, adverse effects of CQ alone or in combination with other drugs were also observed among some patients, who showed mild symptoms such as dizziness, nausea and diarrhoea (Chattopadhyay et al. 2007). In rare occasions, long-term use of CQ may be associated with neuromyopathy and retinopathy (Chattopadhyay et al. 2007). CQ is considered safe for use during pregnancy, but its administration is contraindicated in patients with known hypersensitivity, severe renal and hepatic diseases, a history of epilepsy, and psoriasis. Therefore, when used in the control of viral diseases, contraindication of CQ should be taken into account by evaluation of the physical condition, underlying diseases and comorbidities of the patients. It is hoped that CQ and many other approved clinical drugs can be repurposed to the antiviral treatment of emerging viral diseases that do have other effective antiviral treatment.

Acknowledgements The author was supported by the Natural Science Foundation of China (Grant \#81620108020), Shenzhen Science and Technology Program (Grant No. KQTD20180411143323605) and Guangdong Provincial "Zhujiang Talents Program” (2017).

\section{Compliance with Ethical Standards}

Conflict of interest The authors declare that they have no conflict of interest.

Animal and Human Rights Statement This article does not contain any studies with human or animal subjects performed by the author.

\section{References}

Chattopadhyay R, Mahajan B, Kumar S (2007) Assessment of safety of the major antimalarial drugs. Expert Opin Drug Saf 6:505-521

García-Serradilla M, Risco C, Pacheco B (2019) Drug repurposing for new, efficient, broad spectrum antivirals. Virus Res 264:22-31

Huang C, Wang Y, Li X, Ren L, Zhao J, Hu Y, Zhang L, Fan G, Xu J, Gu X, Cheng Z, Yu T, Xia J, Wei Y, Wu W, Xie X, Yin W, Li H, Liu M, Xiao Y, Gao H, Guo L, Xie J, Wang G, Jiang R, Gao Z, Jin Q, Wang J, Cao B (2020) Clinical features of patients infected with 2019 novel coronavirus in Wuhan, China. Lancet. https://doi.org/10.1016/S0140-6736(20)30183-5

Lo MK, Jordan R, Arvey A, Sudhamsu J, Shrivastava-Ranjan P, Hotard AL, Flint M, McMullan LK, Siegel D, Clarke MO, Mackman RL, Hui HC, Perron M, Ray AS, Cihlar T, Nichol ST, Spiropoulou CF (2017) GS-5734 and its parent nucleoside analog inhibit Filo-, Pneumo-, and Paramyxoviruses. Sci Rep 7:43395

National Health Commission of the People's Republic of China (2020) http://www.nhc.gov.cn/xcs/yqfkdt/202001/e71bd2e7a08 24ca69f87bbf1bef2a3c9.shtml

Rainsford KD, Parke AL, Clifford-Rashotte M, Kean WF (2015) Therapy and pharmacological properties of hydroxychloroquine and chloroquine in treatment of systemic lupus erythematosus, rheumatoid arthritis and related diseases. Inflammopharmacology 23:231-269

Savarino A, Boelaert JR, Cassone A, Majori G, Cauda R (2003) Effects of chloroquine on viral infections: an old drug against today's diseases. Lancet Infect Dis 3(11):722-727

Sheahan TP, Sims AC, Graham RL, Menachery VD, Gralinski LE, Case JB, Leist SR, Pyrc K, Feng JY, Trantcheva I, Bannister R, Park Y, Babusis D, Clarke MO, Mackman RL, Spahn JE, Palmiotti CA, Siegel D, Ray AS, Cihlar T, Jordan R, Denison MR, Baric RS (2017) Broad-spectrum antiviral GS-5734 inhibits both epidemic and zoonotic coronaviruses. Sci Trans Med. https://doi.org/10.1126/scitranslmed.aal3653

Wang M, Cao R, Zhang L, Yang X, Liu J, Xu M, Shi ZL, Hu Z, Zhong W, Xiao G (2020) Remdesivir and chloroquine effectively inhibit the recently emerged novel coronavirus (2019$\mathrm{nCoV})$ in vitro. Cell Res. https://doi.org/10.1038/s41422-020$0282-0$

Warren TK, Jordan R, Lo MK, Ray AS, Mackman RL, Soloveva V, Siegel D, Perron M, Bannister R, Hui HC et al (2016) Therapeutic efficacy of the small molecule GS-5734 against Ebola virus in rhesus monkeys. Nature 531:381-385 
World Health Organization (WHO) (2020a) https://www.who.int/csr/ sars/en/. Accessed 29 Jan 2020

World Health Organization (WHO) (2020b) https://www.who.int/ emergencies/mers-cov/en/. Accessed 29 Jan 2020

World Health Organization (WHO) (2020c) https://www.who.int/ docs/default-source/coronaviruse/situation-reports/20200129sitrep-9-ncov-v2.pdf?sfvrsn=e2c8915_2. Accessed 29 Jan 2020
Zhu N, Zhang D, Wang W, Li X, Yang B, Song J, Zhao X, Huang B, Shi W, Lu R, Niu P, Zhan F, Ma X, Wang D, Xu W, Wu G, Gao GF, Tan W (2020) China Novel Coronavirus Investigating and Research Team (2020) A novel coronavirus from patients with pneumonia in China, 2019. N Engl J Med. https://doi.org/10. 1056/NEJMoa2001017 